\title{
担癌ラットの補体に関する免疫生物学的研究
}

\section{第I編 ラット補体の測定方法}

関西医科大学外科学教室（指導：山本政勝教授）

関西医科大学微生物学教室（指導 : 大山昭夫教授）

瀧 藤 尊 照

I 緒 言

II 実験材料および方法

\section{1 実験材料}

1）実験動物

2) 紱衝 液

1）ベロナール紱衝液保存原液

口) $0.1 \mathrm{mo} / / \ell$ EDTA-Na2 保存原液

八） $2 \%$ ジラン液

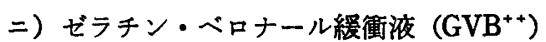

ホ）グルコース・ゼラチン・ベロナール縒衝液 (glucose-GVB ${ }^{++}$)

へ) $0.01 \mathrm{mo} / / \ell \mathrm{EDTA} ・$ ゼラチン・ベロナー ル緩重液 $(0.01 \mathrm{mo} / / \ell$ EDTA-GVB)

3) ラット血清

4) モルモット補体成分 C2（gpC2）

5) ヒッジ赤血球

2 実験方法

1) ラット $\mathrm{CH}_{50}$ の定量法

2) C-EDTA の作製方法

イ) ラット C-EDTA (rat C-EDTA)

ロ）モルモット C-EDTA (gp C-EDTA)

3 ）溶血の中間反応体の作製方法

1) 水水中 $\left(0^{\circ} \mathrm{C}\right)$ での $\mathrm{EAC1} 142$ (EAC142 rat) の作製

\section{I 腥 宫}

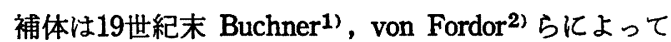
正常血清中に存在する熱に不安定なしかも殺菌作用を有 する物質として取りあげられて以来，急速にその概念が 明確にされるようになった。当初てレキシンと呼ばれて いた補体は，Ritz ${ }^{3)}, \mathrm{Coca}^{4)}$ ，Gordon5) らの研究によ り単一のタンパクではなく, 数種の成分から成りたって いることが報告され，さらに Mayer6) らの詳細な研究
次

口) $\mathrm{gpC} 2$ の希釈度

八） $37^{\circ} \mathrm{C}$ での EAC142rat2gp の作製

$\Rightarrow 20^{\circ} \mathrm{C} て ゙ の$ EAC142rat の作製

4) ラット C142の定量法

5) ラット C3 total の定量法

III 実駼結果

1 ラット $\mathrm{CH}_{50}$ の定量

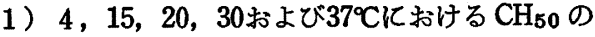
定量

2) ラット $\mathrm{CH}_{50}$ 定量と検量線

2 ラット(C142 titration) およびC 3-C 9 の定 量 (C3 total)

1) 水水中 $\left(0^{\circ} \mathrm{C}\right)$ での EAC142rat の形成

2) モルモット C2 (gpC2) の希喽度

3) EAC142rat2gp の形成

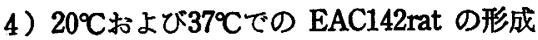

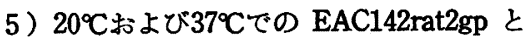
ラット C-EDTA (Crat-EDTA) の反応

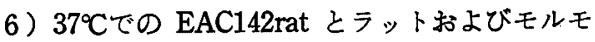
ッ $\mathrm{C}-\mathrm{EDTA}$ との反応

7) ラット C142定量 (C142 titration) と検量線

8) ラット C 3-C9定量 (C3 total) 々検量線

IV 考按

$\mathrm{V}$ 結 論

が進むにつれて補体の反応の発現には，抗体依存性と 抗体非依存性の 2 とおりの経路が存在することも明らか になった。近年前者は古典的経路と呼ばれ，後者はプロ パージン経路7) と呼ばれている。さらに Mayer') らの 溶血反応の Kinetics に関する研究が明らかになるにつ れ，溶血の中間反応体 (intermediate cell) の作成が比 較的容易にできるようになり, 補体免度化学の新しい道 が開かれるに至った。'Borsos8) らはモルモットの中間 反応体 (EAC14gp) を用いてモルモット補体成分 C2（gp 
C2）活性の測定法について報告し, Linscott ${ }^{9)}$, 西岡 ${ }^{10)}$ ら注感作ヒッジ赤血球（EA）と正常モルモット血清完 反応させて, EAC14gp，EAC142gp という中間反応体を 作製するととに成功している。さらに稲井ら ${ }^{11)}$ は, 前 記の中間反応体に $\mathrm{Ca}^{++}, \mathrm{Mg}^{++}$のキレート梸として知ら れているEDTAを組み合わせることによって補体成分の 測定をより簡便化している。また Austen ${ }^{12)}$ ，および Borsos，Rapp 513）も同様な実験法で補体成分の測定 について報告している。さらに稲井(1) 永木ら14)15) は 種族を越えての補体成分の相互反応について検討を行な っている。すなわち，ヒトおよびモルモットの第 1 乃至 第 4 成分をそれされ組み合わせた中間反応体を作成する と同時に, 前述の EDTA の他に $\mathrm{Mg}^{++}$のキレート敖で あるトリエチレンテトラミン $-\mathrm{N}, \mathrm{N}, \mathrm{N}^{\prime}, \mathrm{N}^{\prime \prime}, \mathrm{N}^{\prime \prime \prime}$, $\mathrm{N}^{\prime \prime \prime},-6$ 酶酸（TTHA）を反応過程に加光，より簡易 に且つ再現性の高い中間反応体を作成することに成功し ている。

以上の如く，一般に実験動物として使用されているモ ルモットに関する補体免疫化学には目覚ましい進歩の跡 が見受けられるが, ラットについては現在までのところ ほとんど知られていない。著者は担癌ラットの補体の動 態を知る目的でラット血清中の補体活性測定法について まず基礎的検討を行なったので以下に述べる。

\section{III実硂材料および方法}

\section{1 実駼材料}

\section{1）実㖇動物}

体重150g 前後の wistar-JCL 系雄性ラットを使用し た。

\section{2) 授街液}

イ）ベロナール䌅衝夜保存原液 $\left(4^{\circ} \mathrm{C}\right.$ で保存)

$$
\begin{array}{lr}
\mathrm{NaCl}, & 85.0 \mathrm{~g} \\
5,5-\text { ジェチル・バルビツール酸 } & 5.75 \mathrm{~g} \\
5,5-\text { ジェチル・バルビツール酸-Na } 3.75 \mathrm{~g}
\end{array}
$$

蒸留水を加えて全量を2000到とする。 $\mathrm{pH} 7.5$

） $0.1 \mathrm{mo} / / \ell \mathrm{EDTA}-\mathrm{Na}_{2}$ 保存原液 ( $4{ }^{\circ} \mathrm{C}$ で保存)

$$
\text { エチレンジフミン・テトラフセテー }
$$

$$
\begin{array}{lr}
\stackrel{\mathrm{N}-\mathrm{Na}_{2}}{ }\left(\mathrm{EDTA}-\mathrm{Na}_{2}\right) & 37.23 \mathrm{~g} \\
\mathrm{NaOH} & 4.0 \mathrm{~g}
\end{array}
$$

蒸留水を加えて全量を 1000 比とする。 $\mathrm{pH} 7.5$

八） $2 \%$ ゼラチン液 ( $4{ }^{\circ} \mathrm{C}$ で保存)

ゼラチン (Difco) $20.0 \mathrm{~g}$ に蒸留水を加えて全量を 1000 mととしオートクレーブで溶解する。

） ゼラチン・ベロナール緩衝液 $\left(\mathrm{GVB}^{++}\right)$ ベロナール緩衝液保存原液 $400 m l$
$0.03 \mathrm{mo} / / \ell \mathrm{CaCl}_{2}$ 液
$10 m l$
$0.1 \mathrm{mo} / / \ell \mathrm{MgCl}_{2}$ 液
$10 m l$
$2 \%$ ヂラン液
$100 \mathrm{ml}$

蒸留水を加えて全量 $2000 m$ とする。 $\mathrm{pH} 7.5$

ホ）グルコース・ゼラチン・ベロナール緩衝腋 (glucose-GVB ${ }^{++}$)

$\begin{array}{lr}\text { ベロナール髣衝液保存原液 } & 200 \mathrm{~m} \ell \\ \text { プドウ糖 } & 50 \mathrm{~g} \\ 0.03 \mathrm{mo} \ell / \ell \mathrm{CaCl}_{2} \text { 液 } & 10 \mathrm{~m} \ell \\ 0.1 \mathrm{mo} \ell / \ell \mathrm{MgCl}_{2} \text { 液 } & 10 \mathrm{~m} \ell \\ 2 \% \text { } & 100 \mathrm{~m} \ell\end{array}$

蒸留水を加えて全量2000m とする。 $\mathrm{pH} 7.5$

へ) $0.01 \mathrm{~mol} / \ell \mathrm{EDTA} ・$ ゼラチン・ベロナール紘 衝液 $(0.01 \mathrm{mo} / \ell$ EDTA-GVB)

$$
\begin{array}{ll}
\text { ベロナール絩衝液原液 } & 360 \mathrm{~m} \ell \\
0.1 \mathrm{mo} \ell / \ell \mathrm{EDTA}-\mathrm{Na}_{2} \text { 原液 } & 200 \mathrm{ml} \\
2 \% \text { ラチン液 } & 100 \mathrm{ml}
\end{array}
$$

蒸留水を加えて全量2000m とする。 $\mathrm{pH} 7.5$

\section{3）ラット血清}

ラットの腹部大動脈より採血後, 約 1 時間室温で凝固 させ，その後 $4{ }^{\circ} \mathrm{C} て ゙ 1$ 時間放置して 血餅を收縮させ， 低温 $\left(4^{\circ} \mathrm{C}\right)$ で遠沈分離した血清をー70以下に保存し た。

\section{4）モルモット補体成分 C2 (gpC2)}

Cordis gpC2を使用した。

\section{5）ヒツジ赤血球}

石津製薬kkよりヒッジ赤血球 $(\mathrm{EA})$ 浮遊液 $\left(1.0 \times 10^{9}\right.$ cells $/ m l)$ を購入の上, 水水中 $\left(0^{\circ} \mathrm{C}\right)$ 亿保存した。 $\mathrm{EA}$ は使用に際して生理的食塭水で 2 回洗浄後, 更に glu$\operatorname{cose}-\mathrm{GVB}^{++}$で 1 回洗浄後, $1.0 \times 10^{\circ} \mathrm{cells} / \mathrm{m} \ell$ 亿調整し た。

\section{2 实磁方法}

\section{1）ラット $\mathrm{CH}_{50}$ の定量法}

Mayer の原法に準しEA $\left(5.0 \times 10^{8} \mathrm{cells} / \mathrm{m} \ell\right)$ と希䣋 した $1: 240$ ラットプール血清（ラット10匹以上）とを 反応させ， $50 \%$ 溶血法 $\left(\mathrm{CH}_{50}\right)$ によってラットの補体価 を定量した。

\section{2） C-EDTA の作製方法}

イ) ラット C-EDTA (ratC-EDTA)

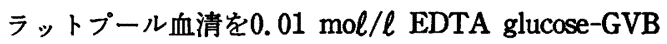
で 1 : 25に希釈して作成した。

ロ）モルモット C-EDTA (gpC-EDTA)

モルモットプール血清（モルモット10匹以上とした） を0. $01 \mathrm{mo \ell} / \ell$ EDTA glucose-GVB で $1: 50$ 亿希釈して 作成した。 


\section{3 ）溶血の中間反応体の作製方法}

1) 永水中 $\left(0^{\circ} \mathrm{C}\right)$ における EAC142 (EAC142rat) の 作製方法

ラットC3〜C9までの活性 (C3 total) を測定するため に EAC142rat 作製した。第 3 図の如く，承水中 $(0$ $\left.{ }^{\circ} \mathrm{C}\right)$ で EA $\left(1.0 \times 10^{9} \mathrm{cells} / \mathrm{m} \ell\right) 20 \mathrm{~m} \ell$ とラットプール血

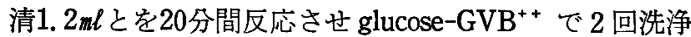
後, $37^{\circ} \mathrm{C} て ゙ 60$ 分間再び反応させ, 形成された EAC142rat を glucose-GVB ${ }^{++}$で 2 回洗浄し， $1.5 \times 10^{8} \mathrm{cells} / \mathrm{ml}$ に調整した。EAC142rat0.25mlに $1: 25$ 亿希䣋した rat C-EDTA 3.0mlを加光， $37^{\circ} \mathrm{C}$ で60分間反応させた後，遠 沈，その上清を O.D. $414 \mathrm{~nm}$ で測定して上記中間反応体 の活性を検討した。

\section{口） $\mathrm{gpC2}$ の希粉度}

EAC142rat2gp を作製すべく，第 4 図の如く $\mathrm{gpC} 2$ の 希釈度について検討した。上記の如く作製した $\mathrm{EAC142}$ rat $\left(1.5 \times 10^{8} \mathrm{cells} / \mathrm{m} \ell\right) 2.0 \mathrm{~m} \ell$ ずつ各試験管に分注の上, さらに glucose-GVB ${ }^{++}$で 1：5から 1：640まで倍数 希釈した $\mathrm{gpC} 22.0 \mathrm{m \ell}$ 加えて $37^{\circ} \mathrm{C} て ゙ 15$ 分間反応させた 後遠沈，その上清を O.D. $414 \mathrm{~nm}$ で測定して，EAC142 rat2gp の溶血活性を検討した。

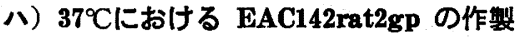

第 5 図の如く承水中 $\left(0^{\circ} \mathrm{C}\right)$ で作成した EAC142rat $\left(1.5 \times 10^{8} \mathrm{cells} / \mathrm{ml}\right) 5.0 \mathrm{~m} \ell$ と $1: 20$ 亿希釈した $\mathrm{gpC} 2$ $5.0 \mathrm{ml} 37^{\circ} \mathrm{C} て ゙ 15$ 分間反応させ，形成された EAC142rat $2 \mathrm{gp}$ を glucose-GVB ${ }^{++}$で 2 回洗浄後, $7.5 \times 10^{7}$ cells/
mlに調整した。EAC142rat2gp $0.5 m \ell$ に $1: 25$ 亿希釈し た ratC-EDTA $3.0 m \ell$ を加え， $37^{\circ} \mathrm{C} て ゙ 60$ 分間反応させ た後，遠沈し，その上清を O.D. $414 \mathrm{~nm}$ で測定して，中 間反応体の活性定検討した。

\section{=) $20^{\circ} \mathrm{C}$ における EAC142rat の作製}

ラットC 1 〜 2 までの活性 (C142) を測定するため

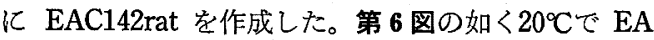
$\left(1.5 \times 10^{8} \mathrm{cells} / \mathrm{m} l\right) 0.25 \mathrm{ml}$ と 1：400に希釈したラッ トプール血清 $0.25 \mathrm{~m} \ell$ とを 45 分間反応させた。形成された EAC142rat $\left(7.5 \times 10^{7} \mathrm{cells} / \mathrm{ml}\right) 1.0 \mathrm{~m} \ell$ K $1: 25$ 亿希釈し た ratC-EDTA 3.0mlを加え, $37^{\circ} \mathrm{C} て ゙ 60$ 分間反応させた 後, 遠沈し，その上清を O.D. $414 \mathrm{~nm}$ で測定して，中 間反応体の活性を検討した。

\section{4) ラットC142の定量法}

第 2 表の如く各試験管に EA $\left(1.5 \times 10^{8} \mathrm{cells} / m \ell\right) 0.25$ mlを注入, 続いて 1：400から 1：6400まで倍数希釈

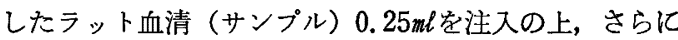
glucose-GVB ${ }^{++} 0.5 \mathrm{ml}$ 加えて全量を $1.0 \mathrm{~m}$ とした。 $20^{\circ} \mathrm{C}$ で 45分間反応後 $1: 25$ 亿希釈した $3.0 \mathrm{mlの} \mathrm{ratC-EDTA}$ を加えて $37^{\circ} \mathrm{C} て ゙ 60$ 分間反応後遠沈，その上清を O.D. $414 \mathrm{~nm}$ で 測定した。

\section{5) ラットC 3 total の定量法}

第 3 表の如く各試験管に EAC142rat2gp $\left(7.5 \times 10^{7}\right.$ cells $/ m \ell$ )を $0.5 m \ell$ ら゙っとり，続いて $1: 600$ 亿希釈した ラット血清（サンプル） $0.5 m \ell 〜 0.9 m \ell$ を注入，さらに $0.01 \mathrm{mo} / / \ell$ の EDTA-glucose-GVBを加えて全量を1.5

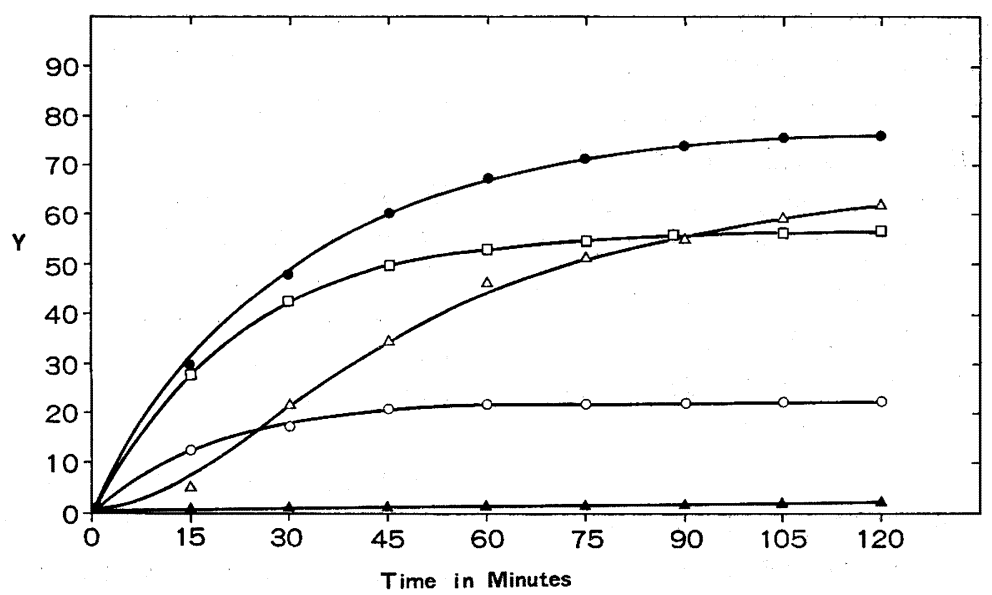

Fig. 1 Kinetics of hemolysis of optimally sensitized sheep erythrocytes by rat complement at different temperatures ( $1: 200$ rat complement) Lysis at different temperatures in glucose gelatin vernnal buffer. Open circles : $37^{\circ} \mathrm{C}$, , open squars : $30^{\circ} \mathrm{C}$, , solid circles : $20^{\circ} \mathrm{C}$, , open triangles $: 15^{\circ} \mathrm{C}$, solid triangles : $4^{\circ} \mathrm{C}$. $\mathrm{Y}=$ percent hemolysis. 
Table 1 Protocol for the Measurement of Complement Hemolytic Activity $\left(\mathrm{CH}_{50}\right)$ in Rat Serum and Results

\begin{tabular}{|c|c|c|c|c|c|c|c|}
\hline No. of tubes & 1 & 2 & 3 & 4 & 5 & 6 & 7 \\
\hline $\begin{array}{l}\text { Glucose gelatin } \\
\text { veronal buffer, } \mathrm{ml} \text {. }\end{array}$ & 1.6 & 1.8 & 1.9 & 2.0 & 2.1 & 2.6 & - \\
\hline $\begin{array}{l}\text { Rat serum }(1: 240) \text {, } \\
\text { ml. }\end{array}$ & 1.0 & 0.8 & 0.7 & 0.6 & 0.5 & - & - \\
\hline Distilled water, ml. & - & - & - & - & - & - & 2.6 \\
\hline $\begin{array}{l}5 \times 10^{8} \text { sensitized } \\
\text { cells }(E A) \text { per } \mathrm{ml}, \mathrm{ml} \text {. }\end{array}$ & 0.4 & 0.4 & 0.4 & 0.4 & 0.4 & 0.4 & 0.4 \\
\hline $\begin{array}{l}\text { Hemolysis, } 0 . D .541 \mathrm{~nm} \\
\text { values }( \pm 0.005)\end{array}$ & $\begin{array}{r}60 n \\
0.455\end{array}$ & $\begin{array}{l}\text { inuts, } \\
0.354\end{array}$ & $\begin{array}{l}20^{\circ} \mathrm{C} . \pm \mathrm{C} \\
0.264\end{array}$ & $\begin{array}{l}.2 \mathrm{c} . \\
0.166\end{array}$ & 0.038 & 0.000 & 0.586 \\
\hline
\end{tabular}

$m \ell$ とした。 $37^{\circ} \mathrm{C} て ゙ 60$ 分間反応後, 生理食塩水 $2.0 m \ell$ を加 えて遠沈，その上清を O.D. $414 \mathrm{~nm}$ で測定した。

\section{III 実驗結果}

1 ラット $\mathrm{CH}_{50}$ の定量

1 ） 4, 15，20，30および37Cにおける $\mathrm{CH}_{50}$ の定

ラット $\mathrm{CH}_{50}$ の測定を行なうための最適の温度条件を 求めるために以下の検討を行なった。

$\mathrm{EA}$ とラット血清を $4,15,20,30$ および $37^{\circ} \mathrm{C}$ 各温 度で反応させ, 反応後 $15,30,45,60,75,90,105$ お よび 120 分ごとに各反応液の溶血の程度を\%で求めた。 その結果は第 1 図に示したように $4{ }^{\circ} \mathrm{C} て ゙ は$ 溶血はほとん ぞ認められないが，15Cでは反応時間がすすむにつれて 徐々に溶血の程度は上昇し始め 120 分後では62\%の溶血 が認められた。20では各反応時間において最も高い溶 血度を示し 120 分後では $76 \%$ の溶血を示した。30² Cで 60分後に53\%の溶血を示したが，それ以後の溶血曲線は ほほプラトーに達した。37ㄷでは45分後に20\%の溶血が 認められたが，反応時間を長くしてもその溶血の度合は ほぼ同じであった。

2 ) ラット $\mathrm{CH}_{50}$ 定国のプロトコールと検量線

第1豪に示したプロトコールのように EA とラット血 清を $20^{\circ} \mathrm{C}$ ，60分間反応させた。その結果ラット $\mathrm{CH}_{50}$ 定 量のための検量線は第 2 図の如く $1 / \mathrm{n}$ は0.26士0.02で, プール血清使用時のラット $\mathrm{CH}_{50}$ は $133 \mathrm{u} / \mathrm{ml}$ であった。

2 ラットC142の定是 (C142 titration) およびラッ, トC $3 \sim$ C 9 の定量（C 3 total）

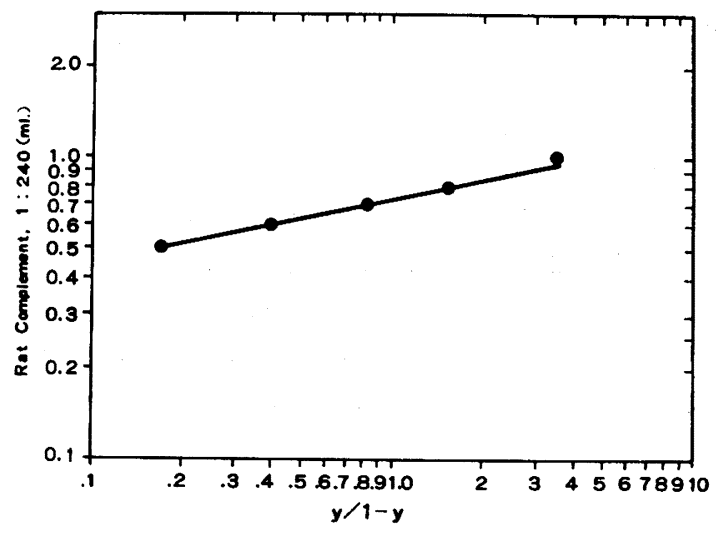

Fig. 2 Measurement of $\mathrm{CH}_{50}$ in rat serum (pooled serum)

Hemolysis of optimally sensitized sheep erythrocytes by rat complement. Logarithmic plot of $\chi$ against $\mathrm{y} / 1-\mathrm{y}$, where $\chi=\mathrm{ml}$. of diluted complement and $y=$ degree of lysis. Dose response curve showed the Von Krogh equation with $1 / n=0.26 \pm 0.02$.

\section{1) 水水中 $\left(0^{\circ} \mathrm{C}\right)$ における EAC142 rat $の$ 形成}

$\mathrm{EA}$ とラット血清を水水中 $\left(0^{\circ} \mathrm{C}\right)$ で反応させ反応後 $3 ， 7.5 ， 15 ， 20 ， 30,45$ および 60 分ごとに各反応液の 溶血の程度を\%で表わした。その結果は第 3 図に示すよ うに，反応後 3 分で $40 \%$ の溶血を示し15分から 20 分間の 反応後には $51 \%$ と最も高い溶血が認められた。その後反 応時間がすすむにつれて溶血の程度はゆるやかな下降傾 向を示した。 


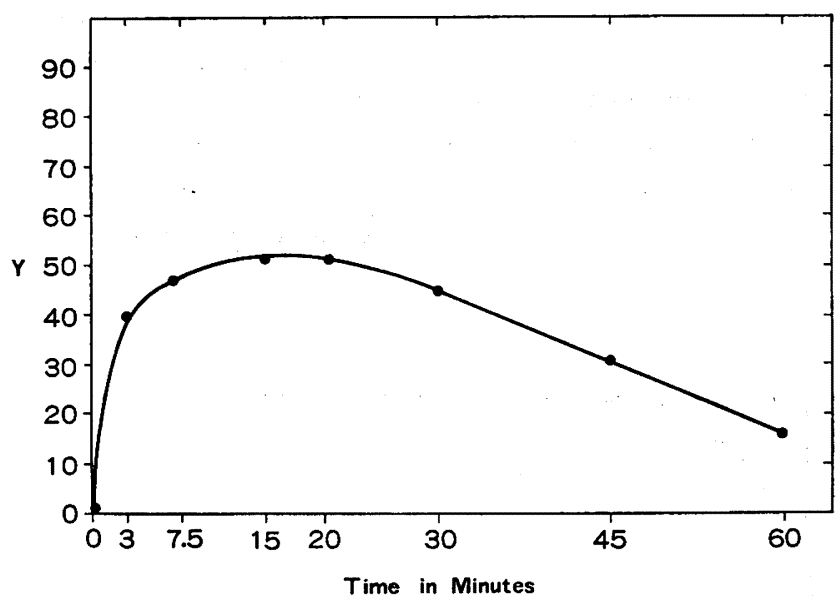

Fig. 3 Kinetics of EAC142rat sites formation at $0^{\circ} \mathrm{C}$ ( $1: 1$ rat complement)

Lysis for 60 minutes at $37^{\circ} \mathrm{C}$. by addition of Crat-EDTA.

$\mathrm{T}_{\max }=20 \min . \mathrm{Y}=$ per cent hemolysis.

2) モルモットC2（gpC2）の希粎度

EAC142ratと1：5から 1：640まで倍数希釈した gp $\mathrm{C} 2$ 2 $37^{\circ} \mathrm{C} て ゙ 15$ 分間反応させた後, EAC142rat2gp の溶 血の程度を\%で表わした。その結果は第 4 図に示すよう に1：5 希橎のとき $94 \%$ と最も高い溶血を示したが, 希釈度が増すにつれて直線的な下降傾向が認められた。

\section{3) EAC142rat2gp の形成}

$0 ， 20 ， 37$ および $40^{\circ} \mathrm{C}$ 各温度で EAC142rat と 1： 20 亿希釈した $\mathrm{gpC} 2$ とを反応させ 反応後 $3,15,30$, $60 ， 120 ， 180$ および 240 分毎に各反応液の溶血の程度を \%で表わした。その結果は第 5 図に示すように水水中 $\left(0^{\circ} \mathrm{C}\right)$ では反応後 3 分で $13 \%$ と軽度の上昇を示した
が、それ以後の反応時間では変化は認められなかった。 $20^{\circ} \mathrm{C}$ では反応時間とともに溶血の程度はゆるやかに増加 し，60分後には98\%に達し，それ以降はほほプラトーに 推移した。37Cでは反応後 3 分で $98 \%$ と非常に高い溶血 度を示し，その溶血度は反応後 30 分まで持続した。その 後は 反応時間がすすむにつれて急速な低下傾向を示し た。 $40^{\circ} \mathrm{Cでは} 37^{\circ} \mathrm{C}$ ほほ同様のパターンの曲線を示し た。

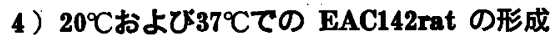

EAと 1：400亿希釈したラット血清とを $20{ }^{\circ} \mathrm{C}$ おび 37 ○で反応させ, 反応後 $5,10,20,30,45$ および 60 分毎 に各反応液の溶血の程度を\%で求めた。その結果は第 6

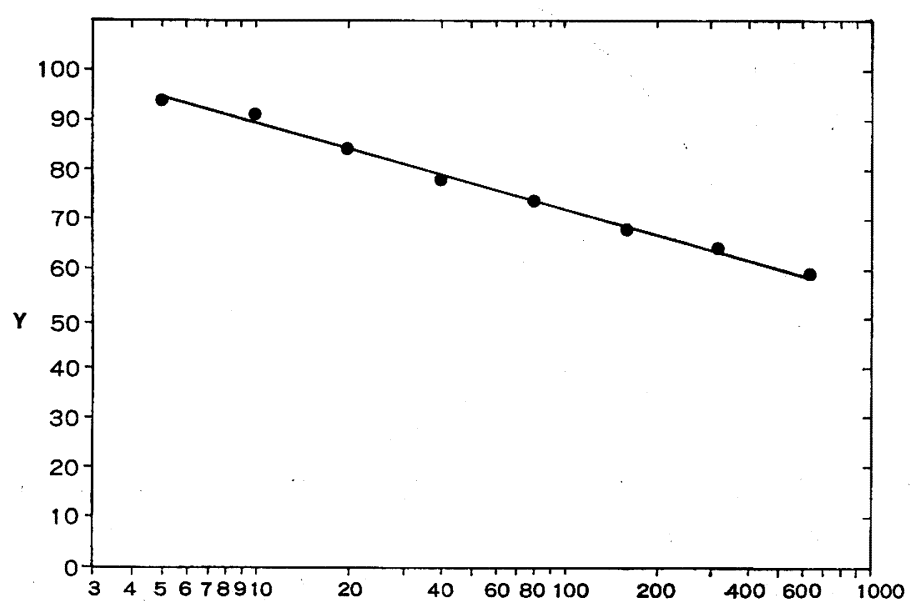

Fig. 4 Dilution of guinea pig C2 
図に示すように20Cでは反応時間とともに溶血の程度は 速やかに上昇し，45分後には84\%に達し以後の溶血曲線 はプラトーに推移した。37Cでは反応後10分で $31 \%$ の溶 血の認められたか，その後は反応時間がすすむにつれ溶 血の程度はゆるやかな下降傾向を示した。

\section{5) $20^{\circ} \mathrm{Cおよび37○での} \mathrm{EAC142rat2gp} \mathrm{とラット}$ C-EDTA（Crat-EDTA) の反志}

EAC142rat2gp と Crat-EDTA $20^{\circ} \mathrm{C} お よ ゙ 377^{\circ} \mathrm{C}$ 反応させ, 反応後 $5,10,20,30,45,60,90$ およ゙ 120 分毎に各反応液の溶血の程度を\%で表わした。その 結果は第 7 图に示すように，20ㄷ゙は 反応時間がすす

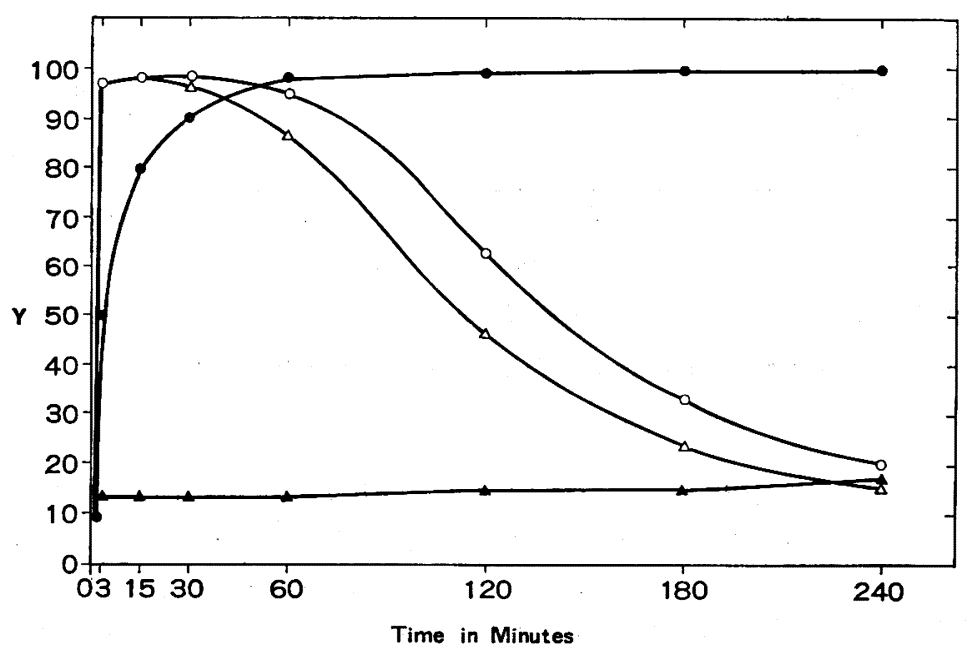

Fig. 5 Kinetics of EAC142rat2gp sites formation and of the decay of EAC142rat2gp at different temperatures

Lysis for 60 minutes at $3^{\circ} \mathrm{C}$. by addition of $\mathrm{C}_{\text {rat }}$-EDTA. Open triangles : $40^{\circ} \mathrm{C}$., $\mathrm{Y}=$ per cent hemolysis.

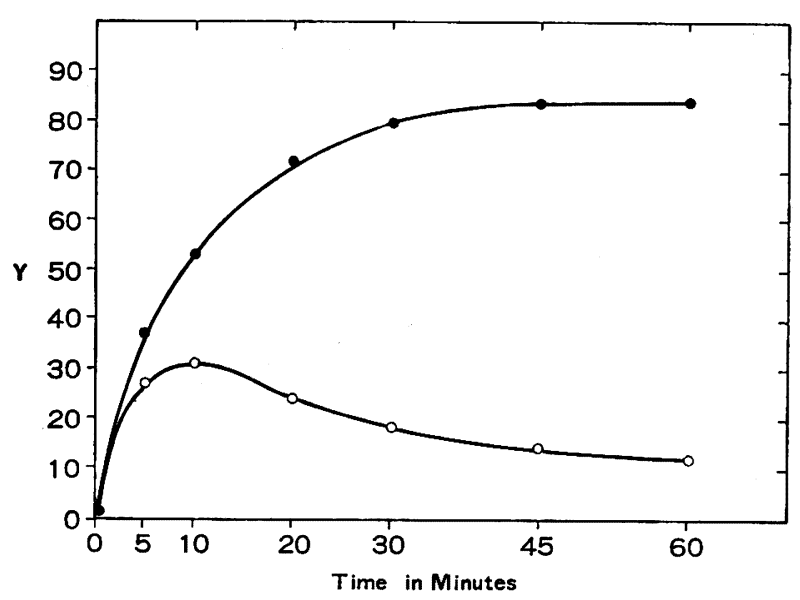

Fig. 6 Kinetics of EAC142rat sites formation at different temperatures (1:400 rat complement)

Lysis for 60 minutes at $37^{\circ} \mathrm{C}$. by addidion of Crat-EDTA. Open circles : $37^{\circ} \mathrm{C}$., solid circles $: 20^{\circ} \mathrm{C}$., $\mathrm{T}_{\max }=45 \mathrm{~min}$. $\mathrm{Y}=$ per cent hemolysis. 


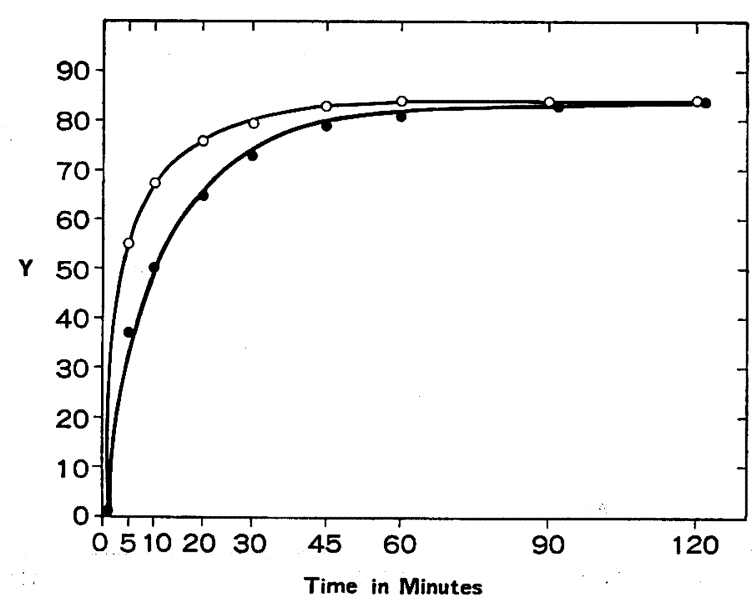

Fig. 7 Kinetic hemolysis curves between EAC142rat2gp and Crat-EDTA at different temperatures

Lysis at different temperatures with $1: 25$ diluted rat complement in $0.01 \mathrm{~mol} / 1$ EDTA glucose gelatin veronal buffer. Open circles : $37^{\circ} \mathrm{C}$, solid circles : 2 olid circles : $20^{\circ} \mathrm{C}$. $\mathrm{Y}=$ per cent hemolysis.

むにつれて溶血の程度は速やかに上昇し，60分後には81 $\%$ と溶血の程度はプラトーに達した。37\% Cでは $20^{\circ} \mathrm{C}$ より むさらに溶血度が高く, 反応後45分には $83 \%$ 示した。

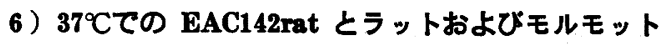
C-EDTA との反化

37Cで EAC142rat とラットおよびモルモットC-

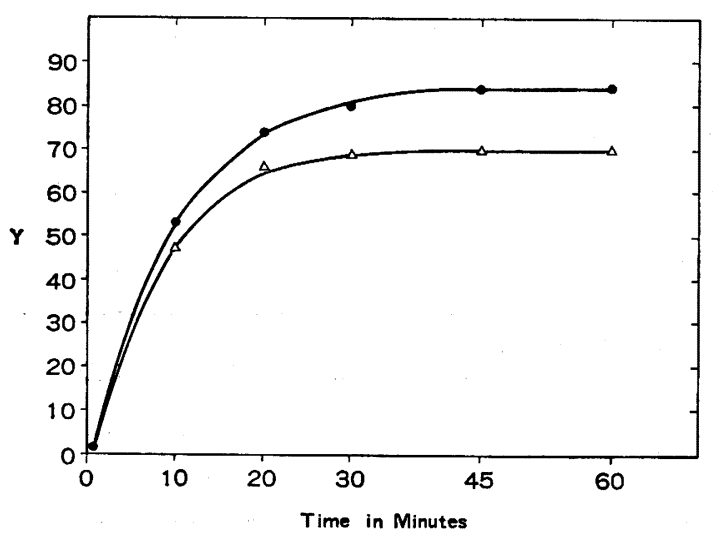

Fig. 8 Kinetic hemolysis curves between EAC142 rat2gp and different C-EDTA at $37^{\circ} \mathrm{C}$.

Lysis for 60 minutes at $37^{\circ} \mathrm{C}$. by addition of C-EDTA. solid circles : $1: 25$ rat complement, open triangles : $1: 50$ guinea pig complement. $\mathrm{Y}=$ per cent hemolysis.

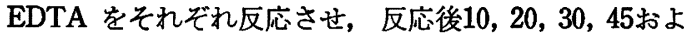
び60分毎に各反応液の溶血の程度を\%で表わした。その 結果㳊第 8 図に示すように 1 ：50亿希䣋したモルモット C-EDTA(C $\mathrm{g}_{\mathrm{g}}$-EDTA)では反応時間がすすむにつれて速 やかに溶血の程度は上昇し反応後 45 分で70\%とほほプラ トーに達した。1：25希釈ラットC-EDTA では CgpEDTA よりも各反応時間において高い溶血を示した。

\section{7）ラットC142定旦と模典線}

第 2 表に示したプロトコールのように EA とラット血 清を20Cで45分間反応させたのち，Crat-EDTA を加え $37^{\circ} \mathrm{C}$ で 60 分間反応させた。その結果ラット C 142 定量の ための検量線は第 9 図の如く $Z=1.0$ のときラット血清

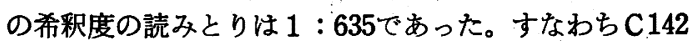
titration $635 \mathrm{SFU} / m \ell$ が得られた。

\section{8 ) ラットC3-C9定旦（C3total）と検贯線}

第3表に示したプロトコールのように EAC142rat 2 gp にラット血清および EDTA-glucose-GVB を加光, $37^{\circ} \mathrm{C}$ で 60 分反応させた。その結果C 3 total のための検 量線は第10図の如く $1 / \mathrm{n}=0.34 \pm 0.03$ であった。すな わちC3 total $709 \mathrm{CH}_{50} / m l$ が得られた。

$$
\text { IV 考按 }
$$

補体は単一の血清タンパクでなく数種類の成分からな っており，しかもある一定の順序に従って反応がすすむ とは20世紀に入ってから明らかにされるようになった。 


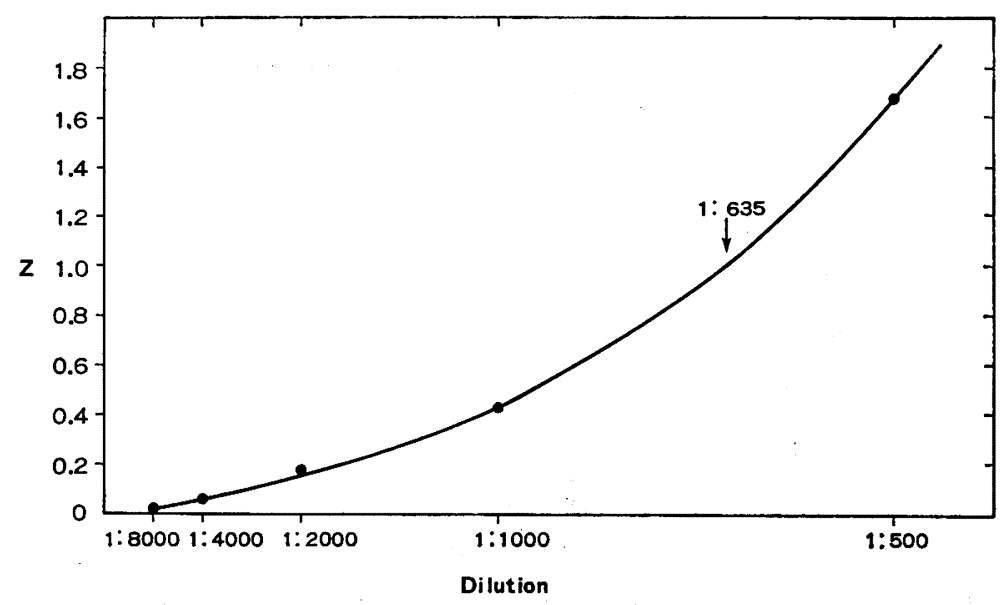

Fig. 9 Resuls of C142 titration in rat serum (pooled serum)

The oxyhemoglobin contents of the supernatants were measured at $414 \mathrm{~nm}$. Then, $Z=-\operatorname{In}(1-\mathrm{y})$, was calculated from the degree of lysis, $y$, and $\log Z$ was plotted against the reciprocal of the dilution of sample.

Table 2 Protcol for the Measurement of C142 Titration in Rat Serum and Results

\begin{tabular}{|c|c|c|c|c|c|c|c|}
\hline No. of tubes & 1 & 2 & 3 & 4 & 5 & 6 & 7 \\
\hline Glucose gelatin veronal buffer, $\mathrm{ml}$. & 0.5 & 0.5 & 0.5 & 0.5 & 0.5 & 0.75 & - \\
\hline $\begin{array}{l}\text { Diluted rat surum, } \mathrm{ml} \text {. } \\
\text { (Dilution of rat serum) }\end{array}$ & $\begin{array}{c}0.25 \\
(1: 400)\end{array}$ & $(1: 800)$ & $(1: 1600)$ & $\begin{array}{l}0.25 \\
(1: 3200)\end{array}$ & $\begin{array}{c}0.25 \\
(1: 6400)\end{array}$ & - & - \\
\hline Distilled water, ml. & - & - & - & - & - & - & 0.75 \\
\hline $\begin{array}{l}1.5 \times 10^{8} \text { sensitized cells (EA) } \\
\text { per } \mathrm{ml}, \mathrm{ml} \text {. }\end{array}$ & 0.25 & 0.25 & 0.25 & 0.25 & 0.25 & 0.25 & 0.25 \\
\hline $\begin{array}{l}\text { Rat complement ( } 1: 25)- \text { EDTA, ml. } \\
\text { (0.O1mol / I EDTA glucose gelatin) } \\
\text { veronal buffer }\end{array}$ & $\begin{array}{l}45 \mathrm{mint} \\
3: 0\end{array}$ & ${ }^{\text {utes }, 20}$ & $\begin{array}{l}{ }^{\circ} . \pm 0.2^{\circ} \mathrm{C} . \\
3.0\end{array}$ & 3.0 & 3.0 & 3.0 & 3.0 \\
\hline O.D. $414 \mathrm{~nm}$ values $( \pm 0.005)$ & $\begin{array}{l}60 \text { minu } \\
0.965\end{array}$ & $\begin{array}{c}\text { ites, } 37^{\circ} \\
0.313\end{array}$ & $\begin{array}{l} \pm 0.2^{\circ} \mathrm{C} . \\
0.164\end{array}$ & 0.101 & 0.058 & 0.038 & 0.809 \\
\hline
\end{tabular}

The oxyhemoglobin contents of the supernatants were measured at $414 \mathrm{~nm}$. When the proportion of the cells lysed was defined as $y$, and-in(1-y) were plotted against the reciprocal of the dilution of sample. 
Table 3 Protocol for the Measurement of C3 Total (C3-C9) Hemolytic Activity in Rat Serum and Results

\begin{tabular}{llllllll}
\hline \multicolumn{1}{c}{ No. of tubes } & 1 & 2 & 3 & 4 & 5 & 6 & 7 \\
\hline $\begin{array}{l}\text { O.01 mol/I EDTA glucose } \\
\text { gelatin veronal buffer, } \mathrm{ml} .\end{array}$ & 0.1 & 0.2 & 0.3 & 0.4 & 0.5 & 1.0 & - \\
$\begin{array}{l}\text { Rat serum }(1: 600), \mathrm{ml} . \\
\text { Disilled water, } \mathrm{ml} .\end{array}$ & 0.9 & 0.8 & 0.7 & 0.6 & 0.5 & - & - \\
$\begin{array}{l}7.5 \times 10^{7} \text { intermediate cells } \\
\text { (EAC } 142 \text { rat } 2 \mathrm{gp} \text { ) per } \mathrm{ml}, \mathrm{ml} .\end{array}$ & 0.5 & 0.5 & 0.5 & 0.5 & 0.5 & 0.5 & 0.5 \\
\hline \begin{tabular}{l} 
Saline, $\mathrm{ml}$. \\
\hline $0.0 .414 \mathrm{~nm}$ values $( \pm 0.005)$
\end{tabular} & 0.540 & 0.472 & 0.393 & 0.322 & 0.248 & 0.094 & 0.921 \\
\hline
\end{tabular}

C3 total hemolytic activity was calculated by the method of $\mathrm{CH}_{50}$ titration.

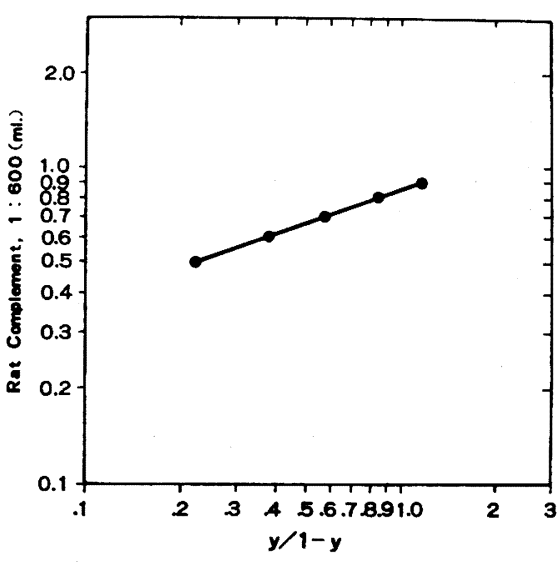

Fig. 10 Measurement of C3 total in rat serum (pooled serum)

Hemolysis of EAC $142 \mathrm{rat} 2 \mathrm{gp}\left(7.5 \times 10^{7}\right.$ cells per ml.) by rat complement. Logarithmic plot of $\chi$ against $\mathrm{y} / 1-\mathrm{y}$, where $\chi=\mathrm{ml}$. of diluted complement and $y=$ degree of lysis. Dose response curve showed the Von Krough equaiton with $1 / \mathrm{n}=0.34 \pm 0.03$.
血清補体中の補体成分 $\mathrm{gpC1}, \mathrm{gpC2}$ を最初に 発見し たのは Ferrata16) である。彼はモルモット血清の透析 を行なって可溶性と不溶性の分画に区別し，当時それぞ れを midpiece, endpiece と呼んだ。不溶性の分画単独, あるいは可溶性の分画単独で核感作ヒッジ赤血球を溶血 することはないが，両者を組み合わせることによって 始めて 溶血が 可能になることを報告している。その後 Pillemer ら7)はザイモザンで血清を処理することで補体

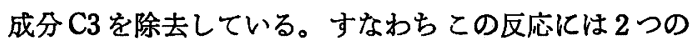
ステップが考えられ，第1ステップは Pillemer らワの 提唱するプロパージンとザイモザンが結合し，第 2 ステ ップはその結果プロパージン・ザイモザン複合体が C 3 を選択的に不活性化すると報告している。また Ritz ${ }^{3)}$, Coca4), Gordon 5) らによって子補体成分 C1，C2，C3, C4 が明確にされ，Pillemer ${ }^{17)}$ はその反応順序をC1, $\mathrm{C} 4, \mathrm{C} 2, \mathrm{C} 3$ 乃至 $\mathrm{C} 4, \mathrm{C} 1, \mathrm{C} 2, \mathrm{C} 3$ とする仮説を打 ちたてた。しかし補体の免疫化学的研究およびその反応 機序などに関して最大の功績を残したのは Mayer') で ある。

従来モルモットの補体活性が $\mathrm{Ca}^{++}, \mathrm{Mg}^{+*}$ によって enhance されることは知られていたが18), Mayer6) は モルモット補体の溶血反応の kinetics に関する詳細な 研究を通じてその根拠を明らかにしている。すなわち(1) $\mathrm{EA}$ は $\mathrm{Ca}^{++}$の存在下で $\mathrm{gpC} 1$ と反応し EAC1gp なる 中間反応体を形成する。(2) EAClgp は gpC4 反反応し EAC14gp を形成する。(3) EAC14gp は $\mathrm{Mg}^{++}$の存在下 
で gpC2を反応し EAC142gp を形成する。(4) EAC142 gp は gpC3 と反応し EAC1423gp を形成するが，これ 以降の反応には 2 価陽イオンを必要としない。(5) EAC 1423gp は適切な条件下で溶解すると述べている。当時 このような事実から補体溶血反応系において中間反応体 が実験操作上比較的容易に作製できるようになり, 補体 系の生物活性を知る上に大いに役にたったといえよう。

Hoffmann, Kabat および Mayer らの) はさらにこれ らの 中間反応体を用いて $\mathrm{gpC} 4$ の溶血活性を測定し, 次 いで稲井ら ${ }^{11)}$ 法従来よりも低イオン強度の希釈液のな かで中間反応体と他の reagent とを反応させることによ って高感度のレベルで, huC4の溶血活性の測定を行な っている。また, 永杖 14) は異なった種属について, 補体成分の相互置換の検討を行なった結果ヒトおよびモ ルモット $\mathrm{C} 1 ， \mathrm{C} 4$ をそれぞれ組み合わせて形成される中 間反応体を他の reagent と反応させ, huC2, gpC2 の溶 血活性の測定を行ない，同時にそれらの中間反応体の 生物学的性状を分析している。すなわち彼らはヒトおよ びモルモットの場合補体成分 $\mathrm{C} 1, \mathrm{C} 4$ を相互置換するこ とが可能であり，種を越えて種々の中間反応を作製する ことができると述べている。

20世紀初期以来 ${ }^{3)}$, 補体汇関する基礎的研究はモルモ ットに関する文献が多く見られるが 6) 18) 20) 21) 22) 23) 24), 担癌モデルとしての研究範囲の広いラットに関す る文献は数が少なく25) 26), ラットの補体活性について 充分に知ることができなかった。とこで今回ラット補体 の生物学的活性ならびに，モルモットの補体成分との相 互反応について検討を行なった。

ラット $\mathrm{CH}_{50}$ 定量はMayer 原法6)の $1: 2.5$ のスケー ルで行なった。第 1 図に示すように20Cで反応させた場 合, 各反応時間において最も高い溶血度が認められた。

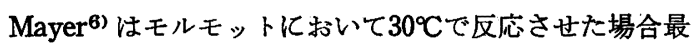
も高い溶血度が得られ，その理由として EAC142 の安 定性によるためとしているが，そのエンドポイントに達 するには 3 時間の反応時間を要している。また, 中間反 応体の安定性以外飞補体活性に影響を及ほすす因子とし て, 制御系因子が考えられる。近年明らかにされつつあ

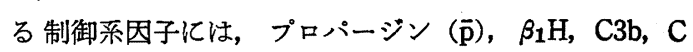
4bINA, C3bINA コファクター (C4bP), $\mathrm{C} 1 \mathrm{INA}^{27}$, 赤血球膜因子， C3NeF 等があげられるが28)，抑制作 用は補体系に特異的なものでなく凝固, 線溶, キニン系 と複雑且つ密接な関係をむってくるので 29) 30) 31) 32) 33)，ラットに関してもこれら制御因子に関する分離精 製法がさらにすすめられることが必要と思われる。また ラット $\mathrm{CH}_{50}$ 定量時の直線勾配は第 2 図に示すように,
$1 / \mathrm{n}=0.26 \pm 0.02$ が得られた。このことは今回の実験 系での溶血素ならびに反応条件が適切であり, 再現性が 高いと言える。次に EA とラット血清とを反応させ得 られる中間反応体について検討を加えてみた。第 3 図に 示すように0 $0{ }^{\circ} \mathrm{C}$ glucose-GVB++ のなかで $\mathrm{EA}$ と原倍 ラット血清を反応させると, 反応後わずか 3 分で $40 \%$ と 溶血の上昇がみられ，約15分で51\%という值を示しなが らプラトーに達しそれ以後は, 反応時間とともにゆるや かな溶血の低下傾向が認められた。このことから EAC 142rat の形成が最高化達する時間 Tmaxは 15分から 20 分の間で, 西岡10) らがモルモットの assay 系で 6 分か ら14分としているのに対し，ラットでは，やや遅延する 傾向がみられた。最大限の EAC142ratを得るためには Tmax の時間だけ正確に反応させる必要があり，ラット の assay 系に関しては EA のロット差も考虑し Tmax を20分とした。但し EAC142rat の場合20分值でも51\% と溶血度が低く中間反応体としては不充分でもう少し高 い溶血度を得たいところである。その他溶血が低い理由 としては, C3以降の反応温度, 反応時間, C3-C9補体成 分などが適当でないことが考えられるが，これらに関し ては後に検討することとし，まず EAC142rat について 若干の検討を加えてみた。第 5 図に示すように，前述の 方法ですでに形成された EAC142rat に0，20，37，40

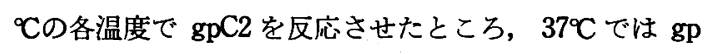
$\mathrm{C} 2$ 添加後わずか 3 分で $97 \%$ と高い溶血を示したが, 反 応30分後から急速な溶血の低下を認めた。 $40^{\circ} \mathrm{Cでもほぼ}$ 同様の結果であった。このことから第 3 図の実験をらり かえると, 氷水中 $\left(0^{\circ} \mathrm{C}\right)$ でラット血清を 20 分反応させ た時形成される中間反応体としては EAC14rat および EAC142rat が考光られ，さらにC2 が結合する site が 相当数残っていると思われる。続いて $\mathrm{gpC}$ を添加した 場合効率良く $\mathrm{gpC} 2$ が結合し EAC14rat2gp および $\mathrm{EAC}$ 142rat2gp ができ, 反応30分後から一旦, 結合した gp C2 が再びはずれていくものと思われる。すなわち $37{ }^{\circ} \mathrm{C}$ で形成された中間反応体は 30 分以上経過すると速やかに その活性を失うため長期保存に耐えられないあのと考 えられる。20ㄷの反応で形成された中間反応体は反応 60 分後に $98 \%$ とほほプラトに達しその後少くとも240分ま では安定を示したことから, この温度では一旦, 結合し た $\mathrm{gpC} 2$ は容易にはずれることがないと考光られる。永 木15)らは TTHA をキレート唷とし EA とヒトおよび モルモット血清とを反応させたときの EAC14hu，EAC 14gp沉つて以下のように述べている。氷水中 $\left(0^{\circ} \mathrm{C}\right)$ の保存条件下で, 前者の場合22日目にオリジナルの $80 \%$ まで溶血度の低下を来し, 後者の場合も22日目に同様の 
結果を示したことから $\mathrm{EAC} 14$ は水水中 $\left(0^{\circ} \mathrm{C}\right)$ の保存 条件で約 14 日間は安定である。また EAC14 の亜型すな わち $\mathrm{EAC} 4, \mathrm{EAC} 142$ の活性湔者で $4 \sim 5$ 日, 後者で 数分後にその活性注低下する。以上のことから, EAC14 rat 乃至 EAC142rat と $\mathrm{gpC} 2$ との結合が可能であり, 反 応条件として $37^{\circ} \mathrm{C}, 15$ 分が適切であると考元られる。次 に第 6 図に示すように $20^{\circ} \mathrm{C}$ および $37^{\circ} \mathrm{C} て ゙ \mathrm{EA}$ と $1: 400$

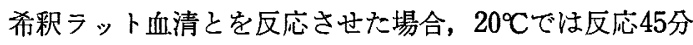
後に 84\%とほぼプラトーに達する高い溶血が認められ

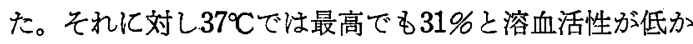
ったことから $1: 400$ 希釈ラット血清 (サンプルとして) 使用時に充分量の EAC142rat を得るためには20で反 応させると最も効率が良く，その時の Tmax った。

一旦形成された中間反応体をさらに溶血に至らしめて その反応性を知るためには，C3以降の残りのC3-C9補体 成分を reagent として充分量を加え反応させなければな らない。ラット血清に $\mathrm{Ca}^{++}$と $\mathrm{Mg}^{++}$のキレート棛とし て知られる EDTA を加えるとラット血清中の C 1, C4, C 2 の反応が阻害されるので Crat-EDTAを C3-C9 補体 成分として使用できることとなる。第 7 図に示すように $37^{\circ} \mathrm{C}$ おび $20^{\circ} \mathrm{C}$ で EAC142rat2gp C Crat-EDTA を反 応させたところ, 各反応時間において反応温度は $37^{\circ} \mathrm{Cが}$ $20^{\circ} \mathrm{C}$ ๖高い溶血を示した。この結果とは逆に第 1 図で 示した如 $く \mathrm{CH}_{50}$ 定量の場合, $37^{\circ} \mathrm{C} て ゙ の$ 溶血活性が極め て低かった事実と考元合わせると，ラットの場合補体活 性が古典的経路ですすむとき $\mathrm{C} 1, \mathrm{C} 4, \mathrm{C} 2$ の補体成分は $20^{\circ} \mathrm{C}$ で反応性が高く, C3-C9 補体成分は $37^{\circ} \mathrm{C} て ゙ 反$ 応性が 高いと言える。またC1からC9 亿至る古典的経路の全反

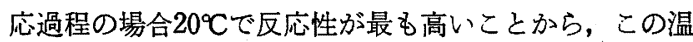
度が規定される時期は $\mathrm{C} 1, \mathrm{C} 4, \mathrm{C} 2$ が反応する時と考え られる。さらに前述の C1 INA, C3b, C4b INA 等の制 御系因子が活性化される温度については不明であり, ラ ット血清中に如何なる制御系因子が存在するかも今後の 研究を待たねばならない。

永木(5) らはヒトおよびモルモット補体成分から形成 される種々の中間反応体 (i.e. EAC14hu, EAC14gp, EAC 142hu, EAC142gp etc.) を溶血に至らしめるためにC3 -C 9 補体成分として 1：50希釈 Cgp-EDTA 定反応さ せているが，今回これについても検討を行なった。第 8 図に示すようにいゔれる最大溶血に至らしめる希釈度と して, ラットでは1:25希䣋, モルモットでは1:50希 釈が得られた。両者を比較する各反応時間において 1 ： 25希釈 Crat-EDTA の方が高い溶血を示した。

以上述べた結果からラット補体成分の assay 系に関し
て若千の結果を得ることができた。すなわち，血清補体 価としての $\mathrm{CH}_{50}$ 定量 (第 1 表), $\mathrm{C} 1-\mathrm{C} 2$ 補体成分活 性測定としての $\mathrm{C} 142$ titration（第 2 表）ならびに C3 -C9補体成分活性測定としてのC3 total（第 3 表）につい てそれぞれの反応条件が得られた。

ラット補体の測定法は次の如く,

1) $\mathrm{CH}_{50}$ 定量注 $5.0 \times 10^{8} \mathrm{cells} / m \ell(\mathrm{EA}) 飞 1: 240$ 希 釈したラット血清を $20^{\circ} \mathrm{C} て ゙ 60$ 分間反応させる。

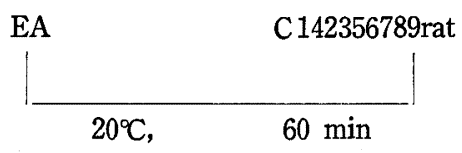

2) C142 titration $\$ 1.5 \times 10^{8}$ cells $/ m \ell(E A)$ K 1 : 400から $1: 6400$ まで倍数希䣋したラット血清を20C 45分間反応する。さらに $1: 25$ に希釈した Crat-EDTA を加え $37^{\circ} \mathrm{C} て ゙ 60$ 分間反応させる。

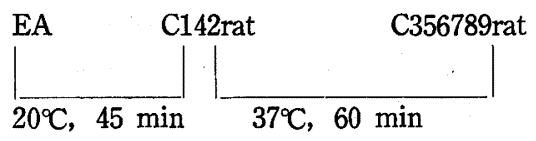

3) C3 total $47.5 \times 10^{7} \mathrm{cells} / m \ell$ のAC142rat $2 \mathrm{gp} に$ $1: 600$ 希䣋した ラット血清を加える。さらに $0.01 \mathrm{~mol}$

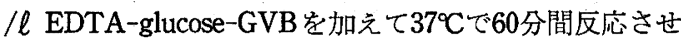
る。

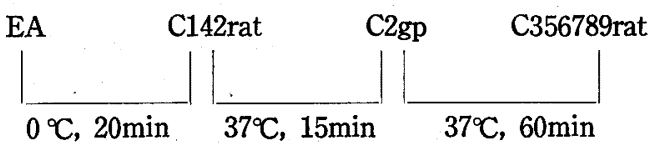

とするのが最適の条件と考えられる。

以上述べてきた測定法ではラット補体各成分を分離精 製する必要は全くなく，ラット血清をそのまま試料とし て使用することにより補体活性を測定することができ た。

すなわち実験操作が簡単で，且つ反応時間も短かくて すみ再現性が高い実験方法であると思われる。今後種々 の実験的環境下におけるラットの補体活性を知る上で有 用な手段と思われる。

\section{$\mathrm{V}$ 結 論}

ラット補体における $\mathrm{CH}_{50}$ 定量, $\mathrm{C} 142$ titration $\mathrm{C} 3$ total の assay 系について実験を行ない次のような結果 を得た。

1. EAとラット血清とを $4,15,20,30$ および $37^{\circ} \mathrm{C}$ の各温度で反応させラット $\mathrm{CH}_{50}$ 定量について検討した 結果, $20^{\circ} \mathrm{C}$ の場合各反応時間において最も高い溶血度を 示した。 
2. EA とラット血清をそのまま水水中（０Ｃ）で反 応させたところ，EAC142rat 形成の Tmax は20分であ った。

3. $0,20,37$ および $40^{\circ} \mathrm{C}$ の各温度で，一旦形成され た EAC14rat に gpC2を反応させたところ， $37^{\circ} \mathrm{C}$ ては 反応速度が最む速く EAC14rat2gp, EAC142rat2gp 形成 の Tmax は15分であった。
4. $20^{\circ} \mathrm{C}$ および $37^{\circ} \mathrm{C}$ 温度で $\mathrm{EA}$ と 1：400希釈ラッ ト血清とを反応させたところ，200の際に 各反応時間 においてより高い溶血度を示し, EAC142rat 形成の Tmax は45分であった。

5. EAC142rat2gp を溶血に至しめるために法，C3C9 補体成分として $1: 25$ 希釈 Crat-EDTA が適切で, その時の反応条件は $37{ }^{\circ} \mathrm{C}, 60$ 分であった。
1) Buchner, H. : Ueber die bakterientödtende Wirkung des Zellenfreien Blutserums. Z bl J. Bakteriol., 5, 817 827, 1889.

2) Von Fodor, J. : Neuere Versuche mit Injection von Bakterien in die Venen. Deut, Med. Wochschr., 12, 617 619, 1886.

3) Ritz, H. : Ueber die Wirkung des Cobragiftes auf die Komplemente. III. Mitteilung. Zugleich ein Beitrag zur Kenntnis der hămolytischen Komplemente. In : Zeitschrift für Immunitätsforschung und experimentelle Therapie, $62 \sim 83$, 1912.

4) Coca, A. F. : A study of the anticomplementary action of yeast, of certain bacteria and of cobra -venom. Z. Immunitsf., 21, 604 622, 1914,

5) Gordon, J., Whitehead, H. R. and Wormall, A. : The action of ammonia on complement. The fourth component. Biochem. J., 20, 1028 1035, 1926.

6) Mayer, M. M. : Complement and complement fixation. In : Kabat and Mayer's Experimental Immunochemistry, Charles C Thomas, Springfield, Illinois U.S.A., 133 240, 1971.

7) Pillemer, L. : Properdin system and immunity II. Interaction of the properdin system with polysaccharides. Science., 122, 545 549, 1955.

8) Borsos, T., Rapp, H. J. and Mayer, M.M. : Studies on the second component of complement. I. The reaction between $\mathrm{EAC}^{\prime} 1,4$ and $\mathrm{C}^{\prime} 2$ : Evidence on the single site mechanism of immune hemolysis and determination of $\mathrm{C}^{\prime} 2$ on a molecular basis. J. Immunol., 87, 310 325, 1961.

9) Linscott, W. D. and Nishioka, K. : Components of guinea pig complement II. Separation of serum fractions essential for immune hemolysis. J. Exp. Med., 118, 795 815, 1963.

10) Nishioka, K. and Linseott, W. D. : Components of guinea pig complement I. Separation of a serum fraction essential for immune hemolysis and immune adherence. J. Exp. Med., 118, 767 793, 1963.

11) Inai, S., Fujikawa, K. and Takahashi, H. : Studies on the fourth component of complement I. Titration of the fourth component in human serum. Biken J., 6, 237 251, 1964.

12) Austen, F. and Beer, F. : The measurement of second component of humen complement (C' $2^{\text {hu }}$ ) by its interaction with EAC' $1 \mathrm{a}^{\mathrm{gp}}$, $4^{\text {gp }}$ cells. J. Immunol., 92, 946 957, 1964.

13) Borsos T. and Rapp, H. J. : Immune hemolysis: A simplefied method for the preparation of EAC' 4 with guinea pig or with human complement. J. Immunol., 99, 263 268, 1967.

14) Nagaki, K., Fujikawa, K. and Inai, S. : Reactivity and compatibility between the second component of complement and EAC' 1, 4 from different component sources. Biken J., 10, 11 $\sim 21,1967$.

15) Nagaki, K., Iida, K. and Inai, S. : A new method for the preparation of EAC14 cell with human or guinea pig serum. Ann. Report of the Center for Adult Deseases, 14, 80 88, 1974.

16) Ferrata, A. : Die Unwirksamkeit der komplexen Hămolysine in salzfreien Lösungen und ihre Ursache. Berlin. klin. Wochschr., 44, 366 $368,1907$. 
17) Pillmer L., Seifter, S., Chu. F., and Ecker EE : Function of components of complement in immune Hemolysis. J. Exper. Med., 76, 93, 1942.

18) Levine, L., Cowan, K. M., Osler, A.G. and Mayer, M. M. : Studies on the role of $\mathrm{Ca}^{++}$and $\mathrm{Mg}^{++}$in complement fixation and immune hemolysis. J. Immunol., 71, 359 366, 1953.

19) Nelson, R. A., Jr., Jensen, J., Gigli, Irma and Tamura, N. : Methods for the separation, purification and measurement of nine components of hemolytic complement in guinea pig serum. Immunochemistry, 3, 111 135, 1966.

20) Bier, O. G., Leyton, G., Mayer, M. M. and Heidelberger, M. : A comparison of human and guinea pig complements and their component fractions. J. Exp. Med., 81, 449 468., 1945.

21) Borsos, T. and Rapp, H. J. : Chromatographic separation of the first component of complement and its assay on a molecular basis. J. Immunol., 91, 851 858, 1963.

22) Nagaki, K., Fujikawa, K. and Inai, S. : Studies on the fourth component of complement II. The fourth component of complement in guinea pig and human platelets. Biken J., 8, 129 141, 1965.

23) Inoue, K. and Nelson, R. A., Jr. : The isolation and characterization of a new component of hemolytic complement, C' 3 e. J. Immunol. 95, 355 367, 1965.

24) Inoue, K. and Nelson, R.A., Jr. : The isolation and characterization of a ninth component of hemolytic complement, C' $3 \mathrm{f}$. J. Immunol., 96, 386 400, 1966.
25）Weimer, H. E. , Meyers, R. L., Miller, J. N., Godfrey, J. and Roberts, D. : Serum complement levels in the albino rat: effects of periodic bleedings. (28477) Proc. Soc. Exp. Biol. Med., 113, 740 742, 1963.

26) Daha, M. R. and Leendert, A. : Isolation of the fourth component ( $\mathrm{C} 4)$ of rat complement. J. Immunol., 123, 2261 2264, 1979.

27) Nagaki, K. and Inai, S. : Inactivator of the first component of human complement ( $\mathrm{C} 1$ INA). Int. Archs Allergy appl. Immun., 50, 172 180, 1976.

28）高田明和, 山下 昭, 近藤元治, 高橋守信編 : 補 体とその周辺，医蒾薬出版，1，19～67, 1981.

29) Müller-Berghaus, G. and Lohmann, E. : The role of complement in endotoxin induced disseminated intravascular coagulation: studies in congenitally $\mathrm{C}_{\boldsymbol{6}}$-deficient rabbits. British $\mathrm{J}$. Haematology. , 28, 403 418, 1974.

30) Garner, R., Chater, B. V. and Brown, D. L. : The role of complement in endotoxin shock and disseminated intravascular coagulation : Experimental observations in the dog. British J. Haematology., 28, 393 401, 1974.

31) Robinson, J. A., Klodnycky, M. L., Loeb, H. S., Racic, M. R. and Gunnar, R.M. : Endotoxin, prekallikrein, complement and systemic vascular resistance. Sequential measurements in man. Amer. J. Med., 59, 61 67, 1975.

32）近藤元治：補体と凝固線溶, 臨床免疫，8，331～ 340, 1976.

33）高田明和, 山下 昭, 近䔕元治, 高橋守信編 : 補 体とその周辺，医歯薬出版， 1， 81 95, 1981. 


\title{
（欧文抄録） \\ Immunobiological Study on the Complement of the Tumor-bearing Rats
}

\section{Part I. The Measurement of Rat Complement}

\author{
Sonsho Takito \\ Department of Surgery, Kansai Medical University, \\ Moriguchi, Osaka, Japan \\ (Director : Prof. Masakatsu Yamamoto M. D. ) \\ (Director : Prof. Akio Ohyama M. D.)
}

The measurement of rat complement was studied on $\mathrm{CH}_{50}$ titration as the total hemolytic complement activity, C142 titration as titration for hemolytic activity of complement component $\mathrm{C} 1-\mathrm{C} 2$, and $\mathrm{C} 3$ total as titration for hemolytic activity of complement component $\mathrm{C} 3-\mathrm{C} 9$, and the following results were obtained :

1. EA (i. e., optimally sensitized sheep erythrocytes) and rat serum were incubated at the temperatures of $15,20,30$ and $37^{\circ} \mathrm{C}$ to study $\mathrm{CH}_{50}$ titration, and the highest hemolytic activity was shown at $20^{\circ} \mathrm{C}$ for each incubation time.

2. When $\mathrm{EA}$ incubated with rat whole serum at $0^{\circ} \mathrm{C}$, EAC142rat sites forming $\mathrm{T}_{\max }$ was $20 \mathrm{~min}$.

3. When EAC14rat and EAC142rat, formed once at each temperature of $0,20,37$ and $47^{\circ} \mathrm{C}$, was incubated with $\mathrm{gpC} 2$, the incubation velocity was maximum at $37^{\circ} \mathrm{C}$, and EAC14rat2gp sites forming $T_{\max }$ was $15 \mathrm{~min}$.

4. When EA was incubated with $1: 400$ diluted rat serum at $20^{\circ} \mathrm{C}$ and $37^{\circ} \mathrm{C}$, the highest hemolytic activity was shown at $20^{\circ} \mathrm{C}$ for each incubation time, and EAC142rat sites forming $T_{\max }$ was $45 \mathrm{~min}$.

5. To hemolyze EAC142rat and EAC142rat2gp, $1: 25$ diluted Crat-EDTA is adequate as the source of complement component $\mathrm{C} 3-\mathrm{C} 9$, and the conditions of incubation were at $37^{\circ} \mathrm{C}$ and for $60 \mathrm{~min}$.

From the above results, the best conditions for the measurement of rat complement are as follows :

1) For the quantitative analysis of $\mathrm{CH}_{50}$, the rat serum is diluted to $1: 240$, reacted for 60 min. at $20^{\circ} \mathrm{C}$ in $5.0 \times 10^{8}$ cells $/ \mathrm{ml}(\mathrm{EA})$. 


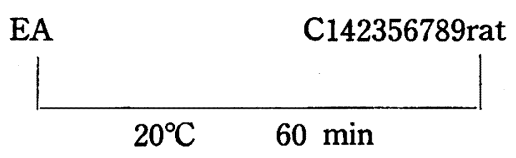

2) For C142 titration, the rat serum, which is diluted by multiples from $1: 400$ to $1: 6400$ is reacted at $20^{\circ} \mathrm{C}$ for $45 \mathrm{~min}$. in $1.5 \times 10^{8}$ cells $/ \mathrm{ml}$ (EA). Next, Crat-EDTA, which is diluted to $1: 25$, is added and the reaction is carried out at $37^{\circ} \mathrm{C}$ for $60 \mathrm{~min}$.

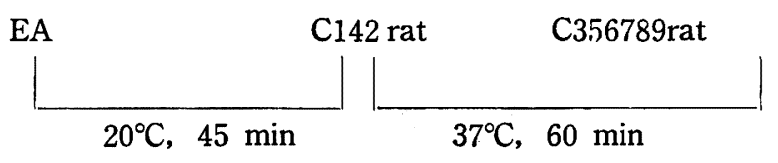

3) For $\mathrm{C} 3$ total quantit y measurement, add the rat serum diluted to $1: 610$ to EAC142 rat2gp of $7.5 \times 10^{7}$ cells $/ \mathrm{ml}$. Next, add $0.01 \mathrm{~mole} / \ell$ EDTA-glucnse-GVB and react them at $37^{\circ} \mathrm{C}$ for $60 \mathrm{~min}$.

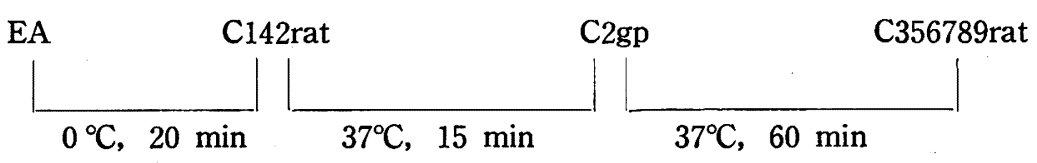

In the assay method established in this experiment, it is not necessary to separate or purify each component of rat complement. Because the sample of rat serum could be used if necessary to measure the complement activity. This experimental procedure may have merit in its simplicity, short end incubation time, and high reproducibility. I think it may be useful to know the complement activity of the rat under various experimental environments for future experiments. 